\title{
"Clone": The History of a Euphonious Scientific Term
}

\author{
URSULA MITTWOCH*
}

"When I use a word", Humpty Dumpty said ... "it means just what I choose it to mean."

It is rare for a scientific term to be adopted by the public, but this has clearly happened to the word clone and its derivative, cloning; and public reaction, dominated by apprehension that cloning might be applied for the production of human babies, has been consistently negative. ${ }^{2}$ To establish the scientific basis from which public opinion stems is not easy. Indeed, the question: "What is a clone?", has no unequivocal answer. In a recent article in Science, Anne McLaren wrote that "Over the years, clones and cloning have meant different things to different people", 3 surely an unsatisfactory state of affairs for a scientific term.

The present article will follow the development of the different uses of the word clone from when it was first coined close to a century ago to the present. I shall argue that the popular identification of a clone with an organism that is akin to a carbon copy of the original is a relic from an earlier stage of the evolution of the term. Indeed, the same point was made by Lee $\mathbf{M}$ Silver in a recent Nature essay. ${ }^{4}$

It would seem that, following the acceptance of Mendelian inheritance at the beginning of the twentieth century, it became widely assumed that organisms are totally specified by the nuclear genotype. This resulted in both scientists and the media ignoring other developmental differences to which organisms are subjected, either for the sake of simplifying the message or with a view to increasing its impact on the public.

* Professor Ursula Mittwoch, Department of Biology, Galton Laboratory, University College London, 4 Stephenson Way, London NW1 2 HE, UK.u.mittwoch@ucl.ac.uk

I am greatly indebted to the Librarians of the British Library, of University College London, The Wellcome Library, The Royal Society of Medicine and the Linnean Society for their help with locating references. I wish to thank Dr Derek Chadwick, Director of the Novartis Foundation, and Ms Jane Dempster, for making available the original tape recordings of the Ciba Foundation Symposium on 'Man and his future', referred to in notes 73 and 84 , and to Professor Stuart Rosen and Mrs Mary Wykes (UCL Phonetics and Linguistic Department) for transcribing them; also Dr Ann Burgess for helpful comments, and Dr Jon Turney and two anonymous referees for constructive criticism of an earlier version of the manuscript.

\footnotetext{
${ }^{1}$ Lewis Carroll, Through the looking glass, and what Alice found there, Basingstoke, Macmillan Children's Books, reprinted 1997 from text of 1897 , p. 113.

${ }^{2}$ The Wellcome Trust, Public perspectives on human cloning: a social research study, London, Wellcome Trust, 1998, p. 4.

${ }^{3}$ Anne McLaren, 'Cloning: pathways to a pluripotent future', Science, 2000, 288: 1775-80.

${ }^{4}$ Lee M Silver, 'What are clones?', Nature, 2001, 412: 21.
} 


\section{Ursula Mittwoch}

\section{Vegetative Reproduction: The Search for a Scientific Term}

The story begins at the turn of the twentieth century, when Herbert J Webber was in charge of the Plant-Breeding Laboratory of the United States Department of Agriculture. In 1899, Webber had travelled to London in order to attend a conference on hybridization, organized by the Royal Horticultural Society, and reported that work on hybridization as a means of securing variation and improvements had only recently begun, chiefly on oranges, pineapples, apples, pears, wheat, corn and cotton. ${ }^{5}$ The year 1900 witnessed the rediscovery of Mendel's paper by three European botanists, ${ }^{6}$ and in the following year an English translation of the paper was published, with a foreword by William Bateson. ${ }^{7}$

While the new science provided increased opportunities for plant breeders, the majority of gardeners and fruit producers seek uniformity rather than variation in their produce, and throughout history they endeavoured to by-pass the participation of ovules and pollen in the propagation of many food plants. Following the dissemination of Mendel's laws, Webber was searching for a scientific term to denote those plants that are propagated vegetatively by buds, grafts, cuttings, suckers, runners, slips, bulbs, tubers, etc. Such plants, he wrote, "are not individuals in the ordinary sense, but are simply transplanted parts of the same individual, and in heredity and in all biological and physiological senses such plants are the same individual". 8

Webber emphasized that he was looking for a term that could be used and understood by the general public. It should, therefore, be short, euphonious, phonetically spelled, easily pronounced and different from any other word in ordinary use, so that it would not suggest any meaning other than the one desired. He suggested the word clon, from the Greek $\kappa \lambda \omega \nu$, meaning a twig, spray or slip, such as is broken off for propagation. Clon (plural clons, adjective clonal) was to be applied to varieties of apples, pears, strawberries, etc., that are not propagated from seeds, to distinguish them from plants such as wheat and corn that are grown from seed. The word was to be pronounced with a long $o$, as in Greek.

Subsequently, Charles Louis Pollard, of Springfield, Massachusetts, suggested an improvement in orthography. ${ }^{9}$ He pointed out that one of the definite indications of quantity in English words was in the final $e$, as in tone, bite, hate etc.; and even though recent American usage had sometimes dispensed with the final $e$, it seemed important to distinguish the derivation from the Greek word $\kappa \lambda \omega \nu$ from that of $\kappa \lambda$ óvos (the latter having given rise to the English adjective clonic). If written clon, the word would naturally be pronounced clön. ${ }^{10} \mathrm{He}$ suggested that clone be adopted as the correct form. The new spelling became widely accepted.

\footnotetext{
${ }^{5}$ Herbert $\mathbf{J}$ Webber, 'Work of the United States Department of Agriculture on plant hybridisation', J. r. hort. Soc., 1900, 24: 128-45, pp. 128, 131-4, 138.

${ }^{6}$ Robert Olby, Origins of Mendelism, 2nd ed., Chicago University Press, 1985, pp. 109-37.

${ }^{7}$ Gregor Mendel, 'Experiments in plant hybridisation. With an introductory note by $\mathbf{W}$. Bateson', J. r. hort. Soc., 1901, 26: 1-32.
}

\footnotetext{
${ }^{8}$ Herbert $\mathbf{J}$ Webber, 'New horticultural and agricultural terms', Science, 1903, 18: 501-3.

${ }^{9}$ Charles Louis Pollard, 'On the spelling of "clon", Science, 1905, 22: 87-8.

${ }^{10}$ Idem, " Clon" versus "Clone", Science, 1905, 22: 469.
} 


\section{"Clone"}

\section{Classical Definitions}

The term clone was defined by Crane and Lawrence as "the collective name of all the plants asexually reproduced by division, grafting, etc., from one (seedling) individual"." The authors pointed out that this method of reproduction had had a prominent place in horticulture for centuries, and was often the only means of perpetuating important varieties. C D Darlington defined clone as "a group of organisms descended by mitosis from a common ancestor". ${ }^{12}$ While this definition would include animals, the examples he discussed were confined to plants bearing an extra chromosome (trisomics), or which are heterozygous for chromosomal changes. Many such plants are sterile, and if they do set viable seed, they fail to breed true.

The definitions given above emphasize that originally clone was a collective noun, referring to a group, all of whose members were descended by vegetative reproduction from a common, sexually produced, ancestor. A B Stout introduced the term ramet to denote the independent members of a clone. ${ }^{13} \mathrm{He}$ added that " $[t]$ he botanical status of the entire group of plants (ramets) constituting a clon is precisely that of the individual plant ... from which the clon was derived". W B Turrill wrote that "with many perennial species hundreds of ramets (the physiologically independent 'individuals' of a clone) can be produced within a year". ${ }^{14} \mathrm{He}$ further stated that these ramets were all of the same genetic constitution, apart from rare somatic mutations, so that a high degree of uniformity could be achieved. The word ramet is included in the Oxford English Dictionary. ${ }^{15}$

It is evident that vegetative propagation plays an important role in ensuring the production of uniform crops of many plants of economic importance, and this fact, coupled with the ease with which the word clone is pronounced and remembered, caused the term to enter into the vocabulary of a wider public. In 1928, The Times printed a Reuters' report stating that the Rubber Research Institute of the Federated Malay States had issued a communiqué, which included the statement that, in a tapping of buddings carried out by the Institute, the highest-yielding clone had latex vessels of much smaller bore than the lowest-yielding clone. This was followed by an explanation in parentheses: "(Note - Clone is the term given to all bud grafts taken from a particular parent tree)" ${ }^{16}$ Some years later, the Economist selected the following item from a chairman's report: "we also have an interest in Namoe Tongan Rubber Estates in Sumatra, which have been planted with selected high yielding clones". ${ }^{17}$

\footnotetext{
${ }^{11}$ M B Crane and W J C Lawrence, The genetics of garden plants, London, Macmillan, 1934, p. 213.

${ }^{12} \mathrm{C}$ D Darlington, Recent advances in cytology, 2nd ed., London, Churchill, 1937, p. 574.

${ }^{13}$ A B Stout, 'The clon in plant life', J. New York bot. Garden, 1929, 30: 25-37, p. 33.

${ }^{14} \mathrm{~W}$ B Turrill, British plant life, London, Collins, 1948, p. 128.
}

\footnotetext{
${ }^{15}$ The Oxford English Dictionary, 2nd ed., Oxford, Clarendon Press, 1989.

${ }^{16}$ Reuters' Report, 'Potential rubber tree yields', The Times, 20 July 1928, p. 20.

17 'Langen (Java) Rubber Estates Company-Improved results-strong position', Economist, 26 Jan. 1935, 120: 212.
} 


\section{Ursula Mittwoch}

However, neither economic success nor popular interest in fruits such as apples, strawberries and bananas inspired the mass media to take an interest in clones. This happened only after the word was applied to organisms that were very different from the crop plants of agriculture and horticulture, and the development of new techniques of culturing them. I shall briefly review the steps that led to consecutive changes in the meaning of the term.

\section{Life Cycles of Protozoa: Clones and Pure Lines}

During the course of the nineteenth century, techniques were developed that allowed protozoa to be cultured and accurately observed under the microscope. In 1888, E Maupas published a detailed description of the methodology for culturing ciliate protozoa, including three species of Paramecium, specifying glassware, and the different food organisms that needed to be present in the drops of water containing the different species of protozoa, both carnivores and vegetarians. Each isolated individual had to be followed on a daily basis, and the same applied to each of its offspring and future generations.

It emerged that these animals could multiply by binary fission for varying numbers of generations, but that eventually the line would die out unless sexual reproduction, in the form of fusion between two individuals, took place. ${ }^{18} \mathrm{~A}$ subsequent investigation by $\mathrm{H}$ S Jennings on variation and inheritance in protozoa, published in 1929, dealt with the question of the extent to which variation can occur between individuals within a line of asexually produced offspring, and contained a subheading 'The occurrence and inheritance of variation within clones, with the results of selection'. ${ }^{19}$ The word clone was defined as follows: "All the individuals descended by uniparental reproduction from a single individual constitute a clone. A single clone has at times been called a 'pure line.' A series of successive generations descended under culture from some member of a clone is commonly spoken of as a line; sometimes as a series. ${ }^{20}$ Selection experiments were undertaken in order to discover whether diverse biotypes, i.e. hereditary constitutions, could be isolated from a single clone.

The concept of the pure line, offered as a synonym for clone, was originally introduced by $\mathrm{W}$ Johannsen ${ }^{21}$ to describe all individuals originating from a single self-fertilizing individual: "Mit einer reinen Linie bezeichne ich Individuen, welche von einem einzelnen selbst-befruchtenden Individuum abstammen" ("by pure line I designate individuals that are descended from a single self-fertilizing individual"). The term "selbst-befruchtenden", i.e. "self-fertilizing", demonstrates that in Johannsen's terminology, the concept of the pure line was applied to a sexually reproducing organism, such as the garden bean, Phaseolus vulgaris, and not to vegetative reproduction.

\footnotetext{
${ }^{18} \mathrm{E}$ Maupas, 'Recherches expérimentales sur la multiplication des infusoires ciliés', Arch. Zool. exp. gén., 1888, 6: 165-277, pp. 191, 179-84, 254-9.

${ }^{19} \mathrm{H}$ S Jennings, 'Genetics of the protozoa', Bibl. Genet., 1929, 5: 105-330, p. 232.
}

\footnotetext{
${ }^{20}$ Ibid., p. 126.

${ }^{21}$ W Johannsen, Ueber Erblichkeit in Populationen und in reinen Linien. Ein Beitrag zur Beleuchtung schwebender Selektionsfragen, Jena, Fischer, 1903, p. 9.
} 


\section{“Clone”}

The admixture of the concepts of clone and pure line was accepted by Robert Harrington in 1975, when he applied the term clone to an hermaphrodite species of fish that reproduces by self-fertilization. He wrote that "Selfing in the wild had already reduced the fish within each of the three lines of our stock to genetic uniformity, viz. isogenicity plus homozygosity. These lines are referred to as homozygous clones. This usage of the term 'clone' avoids repeated circumlocution and means a group or line of descent composed of uniparental, isogenic individuals". 22 The term clone has also been applied to all-female species of lizards belonging to the genus, Cnemidophorus, which reproduce by diploid parthenogenesis and are genetically homogeneous, although many species are heterozygous. ${ }^{23}$

Jennings' 1929 paper had been preceded by an earlier one published in 1916, in which he challenged Johannsen's claim that selection within pure lines was ineffective. According to Jennings, selection of characteristics such as number and length of spines on the shell of the protozoan, Difflugia corona, was effective even within the progeny of a single individual. He did not, however, use the word clone, but family, for all the individuals descended by fission from one original parent. ${ }^{24}$

\section{Cultures of Cells from Multicellular Organisms}

In addition to the study of protozoa, the second half of the nineteenth century also witnessed the development of the scientific study of bacteriology. ${ }^{25}$ Having discovered the nature of fermentation, Louis Pasteur devised special liquid media for their culture, while Robert Koch developed solid media for the isolation of pure cultures.

In the early twentieth century, pathologists adapted the techniques for culturing micro-organisms for the study of human cells and those of other multicellular organisms. ${ }^{26}$ As in bacteria, techniques were worked out to enable quantitative studies to be made of the rate of growth of normal and cancer cells in vitro. However, the problem of obtaining pure cultures from an original inoculum containing many cells proved to be harder than in micro-organisms. ${ }^{27} \mathrm{~A}$ major difficulty that persisted for several decades was that cultures failed to grow unless the original inoculum consisted of a large number of cells. The problem was solved for the first time in 1948 by Katherine Sanford and collaborators at the USA National Cancer Institute. ${ }^{28}$

\footnotetext{
${ }^{22} \mathrm{R}$ W Harrington, 'Sex determination and differentiation among uniparental homozygotes of the hermaphroditic fish, Rivulus marmoratus (Cyprinodontidae: Atheriniformes)', in R Reinboth (ed.), Intersexuality in the animal kingdom, Berlin and New York, Springer, 1975, p. 249.

${ }^{23}$ Charles J Cole, 'Unisexual lizards', Sci. Am., Jan. 1984, 250: 84-90, 118, p. 85.

${ }^{24} \mathrm{H}$ S Jennings, 'Heredity, variation and the results of selection in the uniparental reproduction of Difflugia corona', Genetics, 1916, 1: 407-534, pp. 419, 532-3.

${ }^{25} \mathrm{~W}$ W C Topley and G S Wilson, The principles of bacteriology and immunity, 2 vols,
}

London, Edward Arnold, 1929, vol. 1, pp. 1-14, 212-23.

${ }^{26}$ A Fischer, Tissue culture: studies in experimental morphology and general physiology of tissue cells in vitro, London, William Heinemann (Medical Books), 1925, pp. 19-34.

${ }^{27}$ Henry Harris, The cells of the body: $a$ history of somatic cell genetics, Cold Spring Harbor Laboratory Press, 1995, pp. 31-56.

${ }^{28}$ Katherine K Sanford, Wilton R Earle and Gwendolyn D Likely, 'The growth in vitro of single isolated tissue cells', J. natl. Cancer Inst., 1948, 9: 229-46. 


\section{Ursula Mittwoch}

Their publication carried the following introduction: "One obstacle to the more accurate use of tissue culture, particularly in cancer research, has been the inability to grow a single, isolated, cell into a clone or pure culture."29

The reason for previous failures turned out to be the inadequacy of even the best culture media, which needed extensive modification by large numbers of cells before they could be utilized. Accordingly, the authors reduced the volume of medium surrounding individual cells by growing them in capillary tubes, and also used conditioned medium, in which cells had been grown previously. ${ }^{30}$ The new technique resulted in the establishment of a clone culture of strain L sarcoma-producing cells from mice of the $\mathrm{C} 3 \mathrm{H}$ strain. ${ }^{31}$ Such cultures did not, however, always retain their homogeneity. Some years later, the authors reported that two sub-lines derived from a clone cell culture that had originated from a single cell differed in morphology as well as in their ability to induce sarcomas when injected into mice. ${ }^{32}$

Theodore Puck and Philip Marcus devised a simplified technique for producing cultures of HeLa (human cervical carcinoma) cultures from single cells. Instead of limiting the amount of medium available to individual cells, they plated them out onto a confluent layer of cells that had been killed by irradiation. ${ }^{33}$ In a subsequent publication, Puck and his colleagues gave the following definition of clone: "A clone is a population, all of whose members are descendants from the same single organism" ${ }^{34}$ But can a single mammalian cell be regarded as an organism? And could this definition not be equally applied to any cell culture derived from an individual organism?

The cell cultures obtained by these techniques were probably all transformed cells with abnormal chromosome constitutions. The establishment of cell cultures from a single euploid cell with normal chromosomes proved to be much more difficult. ${ }^{35}$

\section{Cell Cultures from Plants}

Techniques for growing cultures from plant material developed along similar lines to those derived from animal cells. They also presented similar problems when cultures were grown from tissues of cells which, even though they were derived from the same plant, may have had different potentialities. In 1954 a technique was described for obtaining cultures originating from single cells of crown galls on marigold (Tagetes erecta), and of tobacco (Nicotiana tabacum) from normal stems. ${ }^{36}$ The authors referred to these as "plant tissue cultures of single cell origin". This

${ }^{29}$ Ibid., p. 229.

${ }^{30}$ Ibid.

${ }^{31}$ Ibid., p. 245.

${ }^{32}$ Katherine S Sanford, Gwendolyn D Likely, Wilton R Earle, 'The development of variations in transplantability and morphology within a clone of mouse fibroblasts transformed to sarcoma-producing cells in vitro', J. natl. Cancer Inst. 1954, 15: 215-37, pp. 228-9.

${ }^{33}$ Theodore T Puck, Philip I Marcus, 'A rapid method for viable cell titration and clone production with $\mathrm{HeLa}$ cells in tissue culture: the use of X-irradiated cells to supply conditioning factors', Proc. natl. Acad. Sci. USA, 1955, 41 : 432-7.

${ }^{34}$ Theodore T Puck, Philip I Marcus, Steven J Cieciura, 'Clonal growth of mammalian cells in vitro', J. exp. Med., 1956, 103: 273-84, p. 274.

${ }^{35}$ Harris, op. cit., note 27 above, p. 51 .

${ }^{36}$ W H Muir, A C Hildebrandt, A J Riker, 'Plant tissue cultures produced from single isolated cells', Science, 1954, 119: 877-8. 


\section{"Clone"}

work was followed by a more extensive investigation, including cultures from additional plant species, grown from both crown gall and normal tissues. The new publication contained the following statement: ${ }^{37}$

Many single cell clones grew well independently, but some either failed to grow (about 10 per cent) or grew poorly after transfer to agar. The term "clone" is used in accordance with Earl's [sic] $(1955)^{38}$ definition. It seems particularly appropriate, since the single cell came from a heterogeneous mixture and culture propagation is entirely vegetative.

In 1959 Ludwig Bergmann used the term cloning in a publication describing a different technique for isolating single plant cells for tissue culture. ${ }^{39}$

During the same period, Frederick Campion Steward and collaborators developed new techniques for studying the growth of plant cells from tissues that had ceased cell division. This involved, first, the identification of media containing the correct composition of growth-regulating substances. ${ }^{40}$ By exposing small pieces of carrot tissue to a regulated mixture of growth medium and air, phloem tissue which had ceased to grow resumed cell division, and eventually even isolated cells would grow into entire plants, including flowers and seeds. ${ }^{41}$ The derivatives of phloem explants derived from a given plant were referred to as a clone. ${ }^{42}$

In 1970, Steward looked back on the years during which it had become possible to grow entire plants from isolated somatic cells. He considered that all parts of the cells were involved in the changes occurring when a quiescent state returned to cell proliferation. This raised the question whether similar changes could be induced in the cells of animals. Evidence from the experiments of John Gurdon (see below) seemed to show that the nuclei of certain animal cells retained all their genetic information, but that this was released only in contact with the cytoplasm of an enucleated egg.

Perhaps eventually, the equivalent of the plant techniques here described may induce somatic cells of animals to embark directly upon an embryological development, and, perhaps, if this is done, they may even be furnished in some way with the equivalent of a parental blood supply. Such steps present, however, obviously greater orders of difficulty, even if they do not constitute insuperable barriers to the free clonal development of higher animals from somatic cells. $^{43}$

${ }^{37}$ W H Muir, A C Hildebrandt, A J Riker, 'The preparation, isolation, and growth in culture of single cells from higher plants', Am. J. Bot., 1958, 45: 589-97.

${ }^{38} \mathrm{~W}$ R Earle, Communication on 'Pure cell strains', in D C Hetherington (ed.), Annual report to Tissue Culture Association, 1955, as cited by Muir et al. on p. 593, note 37. Extensive enquiries have failed to locate a copy of the report.

${ }^{39}$ Ludwig Bergmann, 'A new technique for isolating and cloning cells of higher plants', Nature, 1959, Aug. 22: 648-9.

${ }^{40}$ E M Shantz, F C Steward, M S Smith, R L Wain, 'Investigations on the growth and metabolism of plant cells. VI. Growth of potato tuber tissue in culture: the synergistic action of coconut milk and some synthetic growthregulating compounds', Ann. Bot., 1955, 19: 49-58.

${ }^{41}$ Frederick Campion Steward, 'The control of growth in plant cells', Sci. Am., Oct., 1963, 209: 104-13.

${ }^{42}$ Frederick Campion Steward, Marion O Mapes, 'The totipotency of cultured carrot cells: evidence and interpretations from successive cycles of growth from phloem cells', J. Indian bot. Soc., 1963, 42A, Maheshwari Commemoration vol., 237-46, pp. 238-242.

${ }^{43}$ Frederick Campion Steward, 'Totipotency, variation and clonal development of cultured cells', Endeavour, 1970, 29: 117-24, p. 124. 


\section{Ursula Mittwoch}

Before taking up the topic of development in animals, two interludes dealing with nomenclature based on immunological science will be inserted.

\section{Interlude 1: \\ The Clonal Selection Theory of Acquired Immunity}

The increasingly widespread use of the word clone and its derivatives for the offspring of single cells in culture is reflected in the title of F Macfarlane Burnet's influential Clonal selection theory of acquired immunity, published in 1959, which dealt with the difficult problem of how cells can make specific antibodies to the vast variety of different pathogens. It could be argued that the impact of the theory was enhanced by the choice of title, which implied scientific novelty and at the same time was easily remembered. Indeed, the author began by saying that in struggling to find titles for lectures or articles, the first that usually came to mind was " $\mathrm{A}$ biological approach to-, or The natural history of (infectious disease, cancer, war)" etc. ${ }^{44}$ The underlying agent of antibody production was not just a cell, but a clone of cells. Moreover, the ecological and evolutionary implications of clones, as opposed to sexually reproducing populations, seemed to represent a simplification of subject matter. This concept could be applied equally to bacteria.

Burnet's theory was based on the premise that antibody-producing cells formed part of a mobile population of mesenchymal cells constantly undergoing physiological and mutational changes. He proposed that, when somatic mutational changes occur, new clones are initiated. ${ }^{45}$ Clones that produce antibody globulins corresponding to particular antigenic determinants will be at a selective advantage, which is expressed by enhanced proliferation. This will result in antibodies being produced to combat the large variety of antigens that may be encountered.

\section{Interlude 2: \\ Monoclonal Antibodies}

For practical purposes, antisera raised by injecting foreign proteins into animals tend to lack sufficient specificity and reproducibility. A way out would be to set up cultures from individual antibody-secreting cells, which produce only one species of antibody, but such cultures fail to survive. In 1975, Georges Köhler and César Milstein overcame this problem by hybridizing lymphocytes, the precursors of antibody-producing plasma cells, with malignant myeloma cells, which can be maintained permanently. ${ }^{46}$ The authors first immunized mice with sheep's red blood cells and then fused (hybridized) their spleen cells with myeloma cells. The hybrid cells secreted antibodies against both parents. Individual cells that produced antibodies against the red blood cells were set up in culture, and the clones could be maintained in culture. In order to become "monoclonal antibodies" in the

\footnotetext{
${ }^{44} \mathrm{~F}$ Macfarlane Burnet, The clonal selection theory of acquired immunity, Cambridge University Press, 1959, pp. 1-2.

${ }^{45}$ Ibid., p. 67.
}

\footnotetext{
${ }^{46}$ Georges Köhler, César Milstein, 'Continuous cultures of fused cells secreting antibody of predefined specificity', Nature, 1975, 256: 495-7.
} 


\section{"Clone"}

immunological sense, however, they needed to undergo additional selection procedures to rid them of determinants derived from the myeloma parent and to express solely antibodies to a single determinant. ${ }^{47}$

Because of the immense impact of the technique on clinical medicine and biological research, César Milstein and Georges Köhler were awarded the Nobel Prize. Hence the term "monoclonal antibodies" is familiar to many scientists other than those specializing in immunology.

\section{Experiments with Enucleated Frogs' Eggs}

We must now address the question of the developmental potential of a nucleus of a differentiated animal cell. Is the effect of the nucleus to direct the development of the phenotype confined along restricted lines, or could even the nuclei of differentiated cells initiate normal embryonic development? The idea of transplanting somatic nuclei into eggs has existed since the end of the nineteenth century, but its successful application had to wait until techniques of activation, enucleation and the transfer of nucleus into the egg had become available. ${ }^{48}$ By the 1950 s sufficient advances had been made to enable Robert Briggs and Thomas King to report successful transplantation in the frog, Rana pipiens. ${ }^{49}$ By removing the nuclei from frogs' eggs and replacing them with nuclei from embryos at the blastula stage, the authors succeeded in raising frogs up to adulthood.

In another series of experiments, King and Briggs made serial transplantations into enucleated frogs' eggs. This included isolating nuclei from a blastula and inserting them singly into enucleated eggs, each of which was allowed to develop into a new blastula. The process was then repeated, using blastulae obtained from the previous experiments. Since it could be assumed that all blastulae so formed contained identical nuclei derived from the original blastula, they were referred to as a "nuclear clone". ${ }^{50}$ Subsequently, the adjective "nuclear" tended to be omitted, and all the offspring of a particular blastula were referred to as a clone.

During the 1960s, John Gurdon carried out transplantation experiments on the South African clawed frog, Xenopus laevis, and in an article in Scientific American, concluded a description of serial nuclear transplantation as follows: "The effect is the same as in the vegetative propagation of plants, namely the production of a clone: a population consisting of many individuals all having an identical set of genes in their nuclei"; while the legend to an illustration explaining serial transplants contained the statement: "The cells' genetically identical nuclei are then transplanted into enucleate eggs, giving rise to a clone: a population comprised of genetically

\footnotetext{
${ }^{47}$ César Milstein, 'Monoclonal antibodies, Sci. Am., Aug. 1980, 243: 66-74.

${ }^{48}$ Marie A Di Berardino, Genomic potential of differentiated cells, New York, Columbia University Press, 1997, pp. 28-53.

${ }^{49} \mathrm{R}$ Briggs, T J King, 'Transplantation of living nuclei from blastula cells into enucleated
}

frogs' eggs', Proc. natl. Acad. Sci. USA, 1952, 38, 455-63.

${ }^{50}$ Thomas J King, Robert Briggs, 'Serial transplantation of embryonic nuclei', Cold Spring Harbor Symp. quant. Biol., 1956, 21: 271-90, p. 277. 


\section{Ursula Mittwoch}

identical individuals". ${ }^{51}$ The individuals themselves were referred to as "transplant frogs".

In a later article, Gurdon speculated on the nature of cytoplasmic molecules that regulate gene activity, but he still maintained that all frogs obtained by the transplantation of nuclei from the same donor embryo into many recipient eggs constituted a clone, "because they are all genetically identical twins"; 52 and again, the comparison is made with vegetative reproduction as practised in plants. This comparison was evidently based on the constancy of the nuclear genome rather than the phenotype resulting from the interaction of any cytoplasmic particles with the genome.

\section{Mitochondrial DNA}

The striking parallelism between the behaviour of chromosomes during meiosis and the transmission of paired Mendelian characters not only persuaded geneticists that the chromosomes within the nucleus were the bearers of the hereditary material, but also gave rise to the supplementary idea that the cytoplasm was devoid of genetic elements. The opposite view, emerging in the 1950s and 1960s, that some DNA was present also in a cytoplasmic component, the mitochondria, ${ }^{53}$ even though supported by increasingly strong evidence, ${ }^{54}$ was at first vigorously rejected. ${ }^{55}$

The relatively massive cytoplasm of frogs' eggs appeared to be particularly rich in mitochondrial DNA. In two species, Rana pipiens and Xenopus laevis, eggs were found to contain 300-500 times more DNA than did somatic cells, and the evidence suggested that most of this DNA was of mitochondrial origin. ${ }^{56}$ But even these findings, as well as others, suggesting that mitochondria contained a few dozen genes, ${ }^{57}$ did not impinge on the expanding use of the term clone and its exclusive connection with nuclear genes.

Mitochondria are the power plants of the cell and are now known to contain genes that are essential for energy generation. In recent years an increasing number of mutations have been identified in human mitochondria that give rise to degenerative diseases, particularly of the brain and of the muscles. ${ }^{58}$ These mutations are inherited solely through the mother. Progressively malfunctioning mitochondria have also been associated with the aging process. Recently it has been established that

\footnotetext{
${ }^{51} \mathrm{~J}$ B Gurdon, 'Transplanted nuclei and cell differentiation', Sci. Am., Dec. 1968, 219: 24-35, pp. $27,28$.

${ }^{52}$ Idem, 'Egg cytoplasm and gene control in development', The Croonian Lecture, 1976, Proc. R. Soc. Lond., B, 1977, 198: 211-47, p. 218.

${ }^{53}$ Sylvan Nass, Margit M K Nass, 'Intramitochondrial fibers with DNA characteristics II. Enzymatic and other hydrolytic treatments', J.. Cell Biol., 1963, 19: 613-29.

${ }^{54}$ D B Roodyn, D Wilkie, The biogenesis of mitochondria, London, Methuen, 1968, pp. 3-10.

${ }^{55} \mathrm{D}$ Wilkie, The cytoplasm in heredity, London, Methuen, 1964, pp. 1-8.
}

\footnotetext{
${ }^{56}$ Igor B Dawid, 'Evidence for the mitochondrial origin of frog egg cytoplasmic DNA', Proc. Natl. Acad. Sci. USA, 1966, 56: 269-76, p. 269.

${ }^{57}$ David Wilkie, 'Early recollections of fungal genetics and the cytoplasmic inheritance controversy', in M N Hall and P Linder (eds), The early days of yeast genetics, Plain View, Cold Spring Harbor Laboratory Press, 1993, pp. 259-69, p. 263.

${ }^{58}$ Douglas C Wallace, 'Mitochondrial DNA in aging and disease', Sci. Am., Aug. 1997, 277 : 40-7.
} 
mitochondrial DNA encodes thirteen polypeptides which interact with a large number of peptides encoded by the nucleus to form the mitochondrial electron transport system. ${ }^{59}$ This suggests that compatibility between the two genetic systems could be important.

Even mammalian eggs, although very much smaller than those of amphibia, contain about 100,000 mitochondria, containing $2 \times 10^{5}$ copies of the mitochondrial genome ${ }^{60}$ compared with about a thousand mitochondria in the cells of somatic cells. ${ }^{61}$ The large number may be in preparation for the energetic demands of embryogenesis. An alternative explanation is that, since mitochondria do not replicate in early embryo development, a large reservoir needs to be present in the oocyte. ${ }^{62}$

Mitochondria control tissue-specific energy production, and there is interaction between the mitochondrial and nuclear genomes. ${ }^{63}$ Even though questions remain regarding detailed mechanisms - and notwithstanding the fact that the number of nuclear human genes exceeds that present in mitochondria by a factor of three magnitudes-there can no longer be any doubt that the question "Do cytoplasmic genes matter?" must be answered in the affirmative.

\section{More Scientific Definitions}

In 1972, Leon Kass published an article opposing different reproductive technologies, and in a section on 'Cloning, or asexual reproduction: state of the art', went into some detail to define the term clone. The author began by saying that "In genetic terms, asexual reproduction is distinguished from sexual reproduction ... by two characteristics: the new individuals are, first, derived from a single parent, and second, genetically identical to that parent". Furthermore, "An unlimited number of identical individuals, i.e., a clone, all generated asexually from a single parent, could be produced by nuclear transplantation" ${ }^{64}$

The first criterion, that an individual produced by asexual reproduction has only a single parent would seem to be questionable in the case of individuals produced by nuclear transplantation into an enucleated egg for two reasons: first, the egg cytoplasm comes from a second individual, and second, the egg is a sexual cell, produced by meiosis, rather than a somatic cell, produced by mitosis. The involvement of the cytoplasm of an egg ensures that the technique has at best some, but not all, the characteristics of asexual reproduction. The correctness of the second criterion is questionable because of the presence of mitochondrial genes in the cytoplasm, which are likely to affect the function of the nuclear genes.

\footnotetext{
${ }^{59}$ Pierre U Blier, France Dufresne, Ronald S Burton, 'Natural selection and the evolution of mtDNA-encoded peptides: evidence for intergenomic co-adaptation', Trends Genet., 2001, 17: $400-6$.

${ }^{60} \mathrm{Jim}$ Cummins, 'Mitochondrial DNA in mammalian reproduction', Rev. Reprod., 1998, 3: 172-82.

${ }^{61}$ Guy Brown, The energy of life, London, HarperCollins, 1999, p. 100.
}

\footnotetext{
${ }^{62}$ Cummins, op. cit., note 60 above, pp. 172-3.

${ }^{63}$ Ibid., pp. 174-5.

${ }^{64}$ Leon R Kass, 'New beginnings in life', in M $P$ Hamilton (ed.), The new genetics and the future of man, Grand Rapids, MI, W B Eerdmans, 1972 , pp. $15-63$, pp. $42-5$.
} 


\section{Ursula Mittwoch}

Kass rejected the notion of those who would confine the term cloning to largescale replication and use the term "nuclear transfer" for single instances of asexual reproduction:

... hoping thereby not to bring the opprobrium of the mass use upon individual cases... . While the term clone does imply an aggregate, it is an aggregate which is formed not horizontally (during one generation) but vertically over time (generation after generation). Thus even the first asexually-produced offspring and his progenitor together form a clone, albeit a small one for the time being. "Nuclear transfer" is but the name of one of several possible techniques that could give rise to a clone and thus does not serve as a generic term for the genetically and humanly significant features of asexual reproduction. Moreover, the desire to avoid for the small-scale use the offensive connotation of mass production begs the question of whether the opprobrium is not equally fitting and leads to the development of euphemism. I shall thus use "cloning" as synonymous with "asexual production, artificially induced." 65

This paragraph was cited by Robert McKinnell in the preface of his book Cloning: nuclear transplantation in amphibia, published in 1978, where he explained the reason for choosing this title: "Biologists generally use the word 'cloning' to refer to the production of multiple genetically identical individuals. Cloned amphibia, in the sense of isogenic groups of frogs, are produced by nuclear transplantation, which is the subject of this book. However, the word 'cloning' is used here in a more general sense, that is, to refer to one or more individuals produced by the method." Kass, McKinnell applied the term cloning to the production of a single individual offspring.

In the same book, the word "clone" is given to a group of frogs that have arisen by nuclear transplantation from a common blastula and therefore are genetically identical, or isogenic. "The terms "isogenic groups", "syngenetic series", and "nuclear transfer clone" are used synonymously in this chapter. Thus "clone" is used here to mean a group, in lieu of its meaning as a mode of asexual reproduction". ${ }^{67}$

In the following year, McKinnell published another book, addressed to the general reader, ${ }^{68}$ of which a revised edition appeared in $1985 .{ }^{69}$ By then, there had been substantial progress in mammalian reproductive technology, including in-vitro fertilization and implantation of embryos into foster mothers. A few mice were claimed to have been born as a result of nuclear transplantation, ${ }^{70}$ and the possibility of using the technology on humans was a subject for speculation, which in turn increased the use of the words clone and cloning among both scientists and the public. According to McKinnell's glossary, the meaning of clone had now been extended to comprise not only the collective, but also the individual: "A group of genetically identical

\footnotetext{
${ }^{65}$ Ibid., p. 43.

${ }^{66}$ Robert G McKinnell, Cloning: nuclear transplantation in amphibia, Minneapolis, University of Minnesota Press, 1978, pp. vii-viii.

${ }^{67}$ Ibid., p. 148.

${ }^{68}$ Idem, Cloning: a biologist reports, Minneapolis, University of Minnesota Press, 1979.
}

\footnotetext{
${ }^{69}$ Idem, Cloning of frogs, mice, and other animals, rev. ed. of Cloning: a biologist reports, Minneapolis, University of Minnesota Press, 1985.

${ }^{70} \mathrm{~K}$ Illmensee, P C Hoppe, 'Nuclear transplantation in Mus musculus: developmental potential of nuclei from preimplantation embryos', Cell, 1981, 23: 9-18.
} 
organisms produced without sexual reproduction; an individual produced asexually". ${ }^{71}$ The presence of the egg cytoplasm continued to be ignored.

In addition to these two definitions, McKinnell also considered that "[t]he production of more than one embryo from separated cells of a single embryo, without the intervention of sex, should be regarded as a form of cloning". ${ }^{22}$ This use of the term seems to have been foreshadowed by J B S Haldane, ${ }^{73}$ but the clones that Haldane envisaged were to be produced by a very different technique.

\section{Gene Cloning}

With the advent of recombinant DNA technology, the term clone acquired yet another meaning for molecular biologists, who extended its use to a segment of DNA that had been multiplied many times. Stanley Cohen and his co-workers constructed bacterial plasmids carrying new combinations of DNA segments. These were inserted into Escherichia coli bacteria, which gave rise to colonies. The authors wrote: "A single clone that had been selected for resistance to kanamycin and which was found also to carry resistance to neomycin and sulfonamide, but not to tetracyclin, chloramphenicol, or streptomycin after transformation of E. coli by EcoRI-generated DNA fragments of R6-5, was examined further". ${ }^{74}$

Subsequently it seemed a small step to extend the terminology from the bacterial clone to the construct of DNA that was contained in it. In Recombinant DNA: a short course James Watson and his colleagues wrote:

Throughout this book we have frequently used the words "cloned", "cloning," and "clone"; recently they have taken on new and, in some quarters, highly emotive meanings. The word "clone" was first used to describe a population of cells or organisms all derived from a single cell or organism by asexual multiplication in such a way that all the individuals in the clone have the same genetic constitution. When it became possible by recombinant DNA techniques to take a gene or any other segment of DNA and multiply it in bacteria, the term "gene cloning" seemed appropriate. ${ }^{75}$

According to a recent definition in Nature, cloning is "[t]he process of generating sufficient copies of a particular piece of DNA to allow it to be sequenced or studied in some other way". ${ }^{76}$

\section{J B S Haldane and Aldous Huxley}

In his essay on science and the future, Haldane considered various possibilities by which progress in biology could contribute to the betterment of humankind. He

${ }^{71}$ McKinnell, op. cit., note 69 above, p. 119.

${ }^{72}$ Ibid., p. 91.

${ }^{73}$ J B S Haldane, 'Biological possibilities for the human species in the next ten thousand years', in G Wolstenholme (ed.), Man and his future, London, J \& A Churchill, 1963, pp. 337-61.

${ }^{74}$ Stanley Cohen, Annie C Y Chang, Herbert W Boyer, Robert B Helling, 'Construction of biologically functional bacterial plastids in vitro', Proc. natl. Acad. Sci. USA, 1973, 70: 3240-4, p. 3241 .

${ }_{75}$ James D Watson, John Tooze and David T Kurtz, Recombinant DNA: a short course, New York, Scientific American Books, 1983, p. 206.

${ }^{76}$ David Baltimore, 'Our genome unveiled', Nature, 2001, 409: 814-16. 


\section{Ursula Mittwoch}

predicted in-vitro fertilization and coined the term ectogenesis for the envisaged development of the embryo and foetus in the laboratory. The proposed advantages of these techniques were that they would counteract the fall in the birth rate that threatened various European countries, and also that they enabled selective breeding from a small proportion of men and women with superior achievements. ${ }^{77}$

The ectogenesis theme was elaborated by Aldous Huxley in his futuristic novel Brave new world, ${ }^{78}$ though mainly for the production of low-caste individuals, who were mass-produced in the manner of Ford motor cars. In Huxley's new world, human reproduction is confined to test-tubes, in which the nutrients are modified to produce individuals of different classes to fit their future stations in life. Those destined to be lower class, Gammas, Deltas and Epsilons, who would be needed to carry out menial tasks, and who are, therefore, required in large numbers, are subjected to a treatment that induces the fertilized egg to divide several times to produce from eight to ninety-six identical individuals. Huxley referred to the technique as "Bokanovsky's Process", and the process of doing so "to bokanovskify".

It should be noted that the method of social engineering described by Huxley relied more on modifying the environment of the developing individuals than their genetic make-up. At the same time, the mass production of desired workers was further promoted by repeated subdivisions of the embryo to be subjected to a specific treatment, thus maximizing the uniformity of the individuals to be produced.

Thirty years later, Haldane returned to the theme of how to improve the human race through advances in biology. A new possibility now seemed on the horizon:

We have known how to grow mammalian cells in culture for over 50 years. Human cells, not only from embryos, children and cancers, but from a sixty-year-old man, have been grown for years on end. We do not know how to induce them to organize themselves. But we may find out at any moment, as we have already found out in some cases of plant cells. It is extremely hopeful that some human cell lines can be grown on a medium of precisely known chemical composition. Perhaps the first step will be the production of a clone from a single fertilized egg, as in Brave New World. But this would be of little social value. The production of a clone from cells of persons of attested ability would be a very different matter, and might raise the possibilities of human achievement dramatically. ${ }^{79}$

In this quotation, Haldane uses the term clone twice. The first, in the reference to Brave new world, relates to the production of multiple individuals from a single fertilized egg by repeated subdivisions of an embryo, "Bokanovsky's Process". To refer to the product of the process as a clone would appear to be a novel use of the term, which, as noted above, was subsequently also adopted by McKinnell. ${ }^{80}$ Haldane, however, dismisses this procedure as of little social value. The second reference is to cell cultures. Many of these would not have originated from single cells, but this fact may not have seemed important to Haldane, provided each culture was derived from a single individual. Since all somatic cells of an individual can be assumed to

${ }^{77}$ J B S Haldane, Daedalus: or, science and the future, London, Kegan Paul, Trench, Trubner, 8th impression, 1928, pp. 63-8, 352.

${ }^{78}$ Aldous Huxley, Brave new world, London, Chatto \& Windus, 1932.
${ }^{79}$ Haldane, op. cit., note 73 above, p. 352.
${ }^{80}$ McKinnell, op. cit., note 69 above, p. 91. 


\section{“Clone"}

have arisen by mitotic divisions from the original fertilized egg, an individual originating from a cell culture would be a clone within the classical definition of the term, i.e. a population of individuals that are descended exclusively from somatic cells, without reference to the number of cells that gave rise to the new individual. ${ }^{81}$

Contrary to the statement by Gina Kolata that Haldane, hooked on the mesmerizing studies by Briggs, King, and later Gurdon, speculated on the results of the frog studies at a scientific symposium, ${ }^{82}$ there is no mention of the frog studies in the symposium proceedings, ${ }^{83}$ including the published discussion on ethical considerations which follows immediately after Haldane's contribution to the Ciba symposium. ${ }^{84}$ What Haldane did envisage was the possibility that techniques might become available to induce human cultured cells to develop into adult individuals, a development that seemed already feasible in plants. One may surmise that he was referring to the work of Frederick C Steward, who succeeded in growing entire carrot plants from somatic cells in culture. ${ }^{85}$ There can be no doubt that Haldane similarly used the term "to clone" for the production of human beings from somatic cells grown in culture, and not for embryos obtained by nuclear transplantation into enucleated oocytes. He added that: "On the general principle that men will make all possible mistakes before choosing the right path, we shall no doubt clone the wrong people". ${ }^{86}$

The juxtaposition of the words clone and cloning with the methods of achieving human reproduction employed by the totalitarian regime described in Huxley's novel may have contributed to increasing public anxiety about advances in human reproductive technologies throughout the following decades. A recent report issued jointly by two British authorities states that "It is clear that the term cloning carries an automatic stigma for many because of its association with imagery such as that portrayed in Brave New World", 87 even though the word does not appear in this book. Indeed, public fear and fascination with the disastrous effects created by the activities of scientists and their predecessors preceded the publication of this novel by more than a thousand years.

\section{Goethe and Mary Shelley}

The origin of Goethe's ballad of the Sorcerer's apprentice, who converted a broom into a servant to fetch water from the well, but then could not stop him even though

\footnotetext{
${ }^{81}$ Darlington, op. cit., note 12 above, p. 574.

${ }^{82}$ Gina Kolata, Clone: the road to Dolly and the path ahead, London, Allen Lane, Penguin Press, 1997, p. 61.

${ }^{83}$ Wolstenholme, op. cit., note 73 above.

${ }^{84}$ Discussion, 'Ethical considerations', in Wolstenholme (ed.), op. cit., note 73 above, pp. 362-83. However, the original tape recording reveals that one participant did ask about the feasibility of allowing a fertilized ovum to
}

\author{
develop to the 8-cell stage, let one cell develop \\ and deep-freeze the other seven, apparently for \\ the purpose of transplantation. \\ ${ }^{85}$ Steward, op. cit., note 41 above. \\ ${ }^{86}$ Haldane, op. cit., note 73 above, p. 352. \\ ${ }^{87}$ Human Genetics Advisory Commission and \\ Human Fertilisation and Embryology Authority, \\ Cloning issues in reproduction, science and \\ medicine, a report, London, Department of Trade \\ and Industry, December 1998, p. 19.
}




\section{Ursula Mittwoch}

the incoming water threatened to flood the entire house, has been traced to a tale by the Greek writer Lucian, ${ }^{88}$ who lived in the second century AD.

Goethe's sorcerer's apprentice followed in the ancient tradition of magicians, who carried out their work by uttering secret incantations on inanimate objects like brooms, or as in the Jewish myth of the Golem, on a piece of clay. ${ }^{89}$ Mary Wollstonecraft Shelley created the archetypal mad scientist in her novel, Frankenstein, first published in 1818. The book is named after its principle character, a Swiss student of anatomy and chemistry, who thought that he had discovered the secret of life and was thus able to bestow animation on lifeless matter. ${ }^{90} \mathrm{He}$ thereupon set out to create a man from materials obtained from the dissecting room and the slaughter house. Alas, the result of his efforts turned out to be a demon, who pursued his creator and finally killed him. The story was further popularized by a successful Hollywood film in $1931,{ }^{91}$ since when the name Frankenstein has become a household word, albeit one that is often transferred from the mad scientist to the monster that he created.

\section{Public Interest: A Glance at the Media}

The experiments in nuclear transfer in frogs were originally undertaken to elucidate the problem of cell and tissue differentiation by providing information on whether the nucleus of an already differentiated cell could substitute for the original nucleus derived by the fusion of egg and sperm. At first, interest in this work was confined to specialists in the field, but before long it entered the domain of a wider public. Already in 1968, one British newspaper proclaimed that "one of the of the most extraordinary of the possibilities now being explored has already been reported under such headlines as 'Einstein from Cuttings' and 'J'aime Mozart XXXIII'. More scientifically it is referred to as 'cloning people'-the creation of genetically identical individuals from body cells". 92

The emergence of a variety of reproductive technologies was undoubtedly a reason for further increasing public interest, while anxiety about their ethical implications gave rise to yet more publicity. Artificial insemination, which had long been used in animal husbandry, came to be applied as a means of assisted reproduction in humans, while the much more complex technique of in-vitro fertilization was debated long before the first "test-tube" baby was born in 1978. ${ }^{93}$ In his critical review of

\footnotetext{
${ }^{88}$ Ludwig Geiger (ed.), Goethe's Werke, 4th ed., 10 vols, Berlin, G Grote, 1890, vol.1, pp. 146-50. "The attribution of the poem to Lucian is based on Struwe, Zwei Balladen von Goethe, verglichen mit griechischen Quellen, woraus sie geschöpft sind, Königsberg, 1826".

${ }^{89}$ Joseph Dan, 'Golem', in R J Z Werblowsky, G Wigoder (eds), The Oxford Dictionary of the Jewish Religion, New York, Oxford University Press, 1997, p. 280.

${ }^{90}$ Mary Wollstonecraft Shelley, Frankenstein, or, the modern Prometheus, 3 vols, London, Lackington, Hughes, Harding, etc., 1818.
} 
reproductive technologies, including in-vitro fertilization and cloning, Leon Kass regarded artificial insemination as the beginning of a slippery slope that would finish with ectogenesis, "the full laboratory growth of a baby from sperm to term". ${ }^{4}$

A year earlier, a well-publicized article by James Watson had appeared entitled 'Moving toward the clonal man. Is this what we want?'. Watson explained that the rapid progress in working out the conditions for test-tube conceptions would before long enable experiments, similar to those that produced clonal frogs, to be carried out with human cells.

The growing up to adulthood of these first clonal humans could be a very startling event, a fact already appreciated by many magazine editors, one of whom commissioned a cover with multiple copies of Ringo Starr, another of whom gave us overblown multiple likenesses of the current sex goddess, Raquel Welch. ${ }^{95}$

Watson's article attracted a reply, casting doubt on the premise that the technique of transplanting a nucleus of a human cell into an enucleated egg would result in a fairly exact copy of the nuclear donor, since "there is plenty of evidence in other creatures that the host egg's cytoplasm would substantially affect the outcome". ${ }^{96}$ However, the possible effect of the cytoplasm on the developing embryos has not, so far, been a matter of public interest.

In the late 1970s, a book appeared that electrified the media and caught scientists unprepared. Its title was In his image: the cloning of a man, and it described the story, which eventually ended successfully, of how the author, David Rorvik, became the chosen intermediary to pave the way for a wealthy man who wished to secure an heir by the new process of "cloning". ${ }^{97}$ The official provenance of the book was "Genetic engineering". Could the story be true, or was it a hoax? Notwithstanding a ten-page bibliography that would have done credit to a textbook, In his image became a best-seller. In the end, following a lawsuit, the publishers (but not the author) admitted that the story was untrue. ${ }^{98}$

Those who thought in 1978 that cloning a human being was "impossible", were likely to change their opinion within the next twenty years. The birth of Dolly the sheep was announced in 1997, albeit without mention of the words "clone" or "cloning"; but these terms were disseminated by the media even before publication day, when the issue of Nature proclaimed "A flock of clones" on its front cover. ${ }^{99}$

Following the birth of Dolly and its handling by the media, cloning issues have generated wide public interest, where promises of unprecedented benefits are counteracted in the public mind by a long tradition of fear that tampering with the natural order of things will lead to disastrous consequences. There is little doubt that simplified terminology has helped people to become familiar with an advance

\footnotetext{
${ }^{94} \mathrm{Kass}$, op. cit. note 64 above, pp. 42-3.

${ }^{95}$ James D Watson, 'Moving toward the clonal man. Is this what we want?', Atlantic Monthly, May 1971: 50-3, p. 51.

${ }^{96}$ Lionel Jaffe, 'Not-so-obsolescent mothers', Atlantic Monthly, July 1971: 25-6.

${ }^{97}$ David M Rorvik, In his image: the cloning of a man, London, Hamish Hamilton, 1978.
}

\footnotetext{
${ }^{98}$ Kolata, op. cit., note 82 above, pp. 101-2.

${ }^{99}$ I Wilmut, A E Schnieke, J McWhir, A J Kind, K H S Campbell, 'Viable offspring derived from fetal and adult mammalian cells', Nature, 1997, 385: 810-13.
} 


\section{Ursula Mittwoch}

in science. Whether it has helped the public understanding of science, or indeed, science itself, is another question.

\section{What's in a Name?}

In order to keep track of the progressive changes in meaning of the scientific term clone, let us consider the summary provided in Table 1 . The different usages fall into four categories: (1) the original, or classical, meaning of the term, i.e. the collective of individuals descended by asexual reproduction from a single organism; (2) cell cultures derived from a single cell; (3) animals produced by the replacement of the nucleus of an oocyte by a diploid nucleus of a somatic cell; (4) the multiplication of genes and other DNA sequences.

As shown in the second section of the Table, the use of the term clone was first extended from garden plants to unicellular protozoa descended by mitosis from a common ancestor. Then, by equating asexually produced protozoa with the pure lines obtained from self-fertilizing flowering plants, Jennings obscured the boundary between vegetative and sexual reproduction, the latter involving germ cells produced by meiosis. The application of the term clone by Sanford and colleagues to mammalian cell cultures originating from a single tissue cell-a technique first successfully performed in 1948-further extended its use to individual cells of multicellular organisms, which would naturally divide by mitosis, whereas the definition by Puck and his fellow workers could also apply to offspring produced by self-fertilization. The clones of complete carrot plants produced by Steward and Mapes in the late 1950s are closest to the classical definition, apart from the fact that the carrots were produced from single somatic cells rather than macroscopic pieces of plants.

Also during the 1950s, the term clone began to be used for the offspring produced by replacing the nuclei of oocytes with nuclei of somatic cells (Table 1 , section 3 ). While the cell culture terminology could be viewed as an extension of the classical usage, the nuclear replacement technique added a new dimension, since it was applied to offspring originating from an egg, albeit an enucleated one. Other changes followed. While the use of many nuclei from the same embryo for nuclear replacement led to the definition of a clone as a population of genetically identical individuals, this in turn gave rise to the idea of identical twins being clones, and that, moreover, all clones originate in asexual, or even vegetative, reproduction. Eventually the term was extended from the collective to the individuals composing it.

As indicated in the last section of the Table, with the rise of molecular genetics, its practitioners adopted the term cloning for their own technique of multiplying sequences of DNA. Today, this usage is widely employed by molecular geneticists, but it is the nuclear replacement technique that has given rise to Dolly that has caught the interest of the public.

\section{Ambiguous Nomenclature}

Defining a clone as a population of genetically identical individuals is no longer accurate, since an investigation of the mitochondrial DNA (mtDNA) of Dolly and 


\section{“Clone"}

Table 1:

Changes in the usage of the term clone, resulting in four categories of meaning

\begin{tabular}{|c|c|c|}
\hline Year & Definition & Author \\
\hline 1903 & $\begin{array}{l}\text { The collection of plants propagated vegetatively from a common } \\
\text { ancestor. }\end{array}$ & Webber ${ }^{\mathrm{i}}$ \\
\hline 1934 & $\begin{array}{l}\text { Collective name of all the plants asexually reproduced by } \\
\text { division, grafting, etc., from one (seedling) ancestor. }\end{array}$ & Crane and Lawrence ${ }^{\mathrm{ii}}$ \\
\hline 1937 & $\begin{array}{l}\text { A group of organisms descended by mitosis from a common } \\
\text { ancestor. }\end{array}$ & Darlington $^{\mathrm{iii}}$ \\
\hline 1929 & $\begin{array}{l}\text { All individual protozoa descended by uniparental reproduction } \\
\text { (i.e. binary fission) from a single individual. In addition, the } \\
\text { concept of clone was equated with that of a pure line, i.e. the } \\
\text { descendants of a single self-fertilizing individual. }\end{array}$ & Jennings $^{\mathrm{iv}}$ \\
\hline 1948 & $\begin{array}{l}\text { Mammalian cell cultures originating from a single isolated tissue } \\
\text { cell. }\end{array}$ & Sanford, et al. ${ }^{\mathrm{v}}$ \\
\hline 1956 & $\begin{array}{l}\text { "A clone is a population of cells whose members are descendent } \\
\text { from the same single organism". }\end{array}$ & Puck, et al. ${ }^{\mathrm{i}}$ \\
\hline 1958 & Cultures originating from single cells of flowering plants. & Muir, et al. \\
\hline 1959 & $\begin{array}{l}\text { The word cloning used for the technique of growing cultures } \\
\text { from isolated plant cells. }\end{array}$ & Bergmann $^{\text {viii }}$ \\
\hline 1963 & $\begin{array}{l}\text { Complete carrot plants derived from a particular strain by } \\
\text { culturing individual somatic cells. }\end{array}$ & Steward and Mapes ${ }^{\mathrm{ix}}$ \\
\hline 1956 & $\begin{array}{l}\text { Serial transplantation of isolated nuclei from frog blastulae into } \\
\text { enucleated oocytes give rise to nuclear clones. }\end{array}$ & King and Briggs $^{x}$ \\
\hline 1968 & A population of genetically identical individuals. & Gurdon ${ }^{\mathbf{x i}}$ \\
\hline 1972 & $\begin{array}{l}\text { Cloning is synonymous with asexual reproduction artificially } \\
\text { induced. A single parent and offspring so produced form a clone. }\end{array}$ & Kass $^{\mathrm{xii}}$ \\
\hline 1975 & $\begin{array}{l}\text { All frogs obtained by transplantation from the same embryo are } \\
\text { identical twins. Their origin is akin to vegetative reproduction. }\end{array}$ & Gurdon ${ }^{x i i i}$ \\
\hline 1985 & $\begin{array}{l}\text { A group of genetically identical organisms; an individual } \\
\text { produced asexually. }\end{array}$ & McKinnell ${ }^{\mathrm{xiv}}$ \\
\hline
\end{tabular}

1983 A gene or other piece of DNA multiplied in bacteria.

Watson $^{\mathbf{x v}}$

'Herbert J Webber, 'New horticultural and agricultural terms', Science, 1903, 18: 501-3.

ii B Crane and W J C Lawrence, The genetics of garden plants, London, Macmillan, 1934, p. 213.

iii C D Darlington, Recent advances in cytology, 2nd ed., London, Churchill, 1937, p. 574.

iv S Jennings, 'Genetics of the protozoa', Bibl. Genet., 1929, 5: 105-330, p.232.

'Katherine K Sanford, Wilton R Earle and Gwendolyn D Likely, 'The growth in vitro of single isolated tissue cells', J. natl. Cancer Inst., 1948, 9: 229-46.

viTheodore T Puck, Philip I Marcus, Steven J Cieciura, 'Clonal growth of mammalian cells in vitro', J. exp. Med., 1956, 103: 273-84, p. 274.

viiw H Muir, A C Hildebrandt, A J Riker, 'The preparation, isolation, and growth in culture of single cells from higher plants', Am. J. Bot., 1958, 45: 589-97, p. 593.

viii Ludwig Bergmann, 'A new technique for isolating and cloning cells of higher plants, Nature, 1959, Aug. 22: 648-9.

${ }^{\mathrm{ix}}$ Frederick Campion Steward, Marion $\mathrm{O}$ Mapes, 'The totipotency of cultured carrot cells: evidence and interpretations from successive cycles of growth from phloem cells', J. Indian bot. Soc., 1963, 42A, Maheshwari Commemoration vol., 237-46, pp. 238-42.

'Thomas J King, Robert Briggs, 'Serial transplantation of embryonic nuclei', Cold Spring Harbor Symp. quant. Biol., 1956, 21: 271-90, p. 277.

xiJ B Gurdon, 'Transplanted nuclei and cell differentiation', Sci. Am., Dec. 1968, 219: 24-35, pp. $27,28$.

${ }^{x i}$ Leon R Kass, 'New beginnings in life', in M P Hamilton (ed.), The new genetics and the future of man, Grand Rapids, MI, W B Eerdmans, 1972, pp. 15-63, 42-5.

xiiiJ B Gurdon, 'Egg cytoplasm and gene control in development', The Croonian Lecture, 1976, Proc. R. Soc. Lond., B, 1977, 198: $211-47$, p. 218

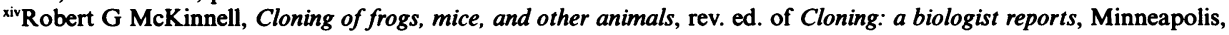
University of Minnesota Press, 1985, p. 119.

xvJames D Watson, John Tooze and David T Kurtz, Recombinant DNA: a short course, New York, Scientific American Books, 1983, p. 206. 


\section{Ursula Mittwoch}

nine other sheep produced by somatic nuclear transfer showed that the mtDNA was derived from the cytoplasm of the enucleated oocytes, thus making the sheep "genetic chimeras". ${ }^{100}$ Furthermore, the statement by Gurdon and Colman ${ }^{101}$ that the mtDNA of mammalian clones is entirely maternal in origin is surely significant. If a clone originates from a nuclear donor plus an egg cytoplasm of maternal, i.e. "mother" origin, the idea that it is derived from a single parent has evidently been abandoned, while its origin in asexual reproduction is questionable.

Ambiguous nomenclature with regard to eggs developing into embryos by unorthodox pathways is not confined to cloning. Half a century ago, Alan Boyden questioned the appropriateness of referring to parthenogenesis as asexual reproduction and emphasized that "there is no such thing as an asexual egg". ${ }^{102}$ The history of an egg's development is at least as important as its subsequent fate, and a modification of sexual reproduction is not to be confused with asexual reproduction. Similarly, and apparently independently, I myself pointed out in 1978 that, since parthenogenesis involves the production of an egg, which plays an essential role in the development of the embryo, the process should be regarded as incomplete sexual reproduction. ${ }^{103}$ On the other hand, the reason given by Roger Hughes for regarding parthenogenesis as not "strictly clonal" is that the process can proceed by different routes that do not necessarily preserve the maternal genotype. ${ }^{104}$

Whereas parthenogenesis remained an issue that has been largely confined to scientists, the topic of clones and cloning has become of increasing concern to the public. While scientists in different specialties still attach different meanings to the terms, the public and popular scientific journals identify them with the technique that has given rise to Dolly. ${ }^{105}$

In order to clarify the terminology of cloning as potentially applicable to humans, it has been subdivided into two apparently distinct meanings: "reproductive cloning", defined as "where an entire animal is produced from a single cell by asexual reproduction", and "therapeutic cloning", involving nuclear replacement technology not leading to the creation of identical individuals. ${ }^{106}$ This evades the question whether the process of embryo splitting that leads to the formation of identical twins is included in the first category, even though this technique has been described as cloning. ${ }^{107}$ It has also recently been pointed out that the identification of "nuclear replacement" with cloning leads to confusion, since replacement by two haploid cells

\footnotetext{
${ }^{100}$ Matthew J Evans, Cagan Gurer, John D Loike, Ian Wilmut, Angelika E Schnieke, Eric A Schon, 'Mitochondrial DNA genotypes in nuclear transfer-derived cloned sheep', Nat. Genet., 1999, 23: $90-3$.

${ }^{101}$ J B Gurdon, Alan Colman, 'The future of cloning', Nature, 1999, 402: 743-6, p. 743.

${ }^{102}$ Alan Boyden, 'Is parthenogenesis sexual or asexual reproduction?', Nature, 1950, 166: 820.

${ }^{103}$ Ursula Mittwoch, 'Parthenogenesis', J. med. Genet. 1978, 15: 165-81, pp. 165-6.

${ }^{104}$ Roger N Hughes, $A$ functional biology of clonal animals, London, New York, Chapman and Hall, 1989, p. 8.
} 


\section{"Clone"}

could lead to biparental inheritance. ${ }^{108}$ A more accurate term to describe the Dolly technique would be: somatic nuclear replacement of an oocyte nucleus.

The multitude of meanings that have accumulated over the years is in stark contrast to the expressed purpose of the originator of the term clon, which was to describe an assemblage of cultivated plants propagated vegetatively rather than by seed, and which should not suggest any other meaning. ${ }^{109}$ Why did this purpose fail? Could it be that the additional desiderata put forward by Webber, that the word should be short, euphonious, phonetically spelled and easily pronounced, unfitted it as a scientific term, whose characteristics have been described as constancy of meaning, ugliness and emotional neutrality? ${ }^{110}$ True, the large majority of scientific terms, dating from Chaucer to the twentieth century, are polysyllabic ${ }^{111}$ and often not easy to memorize. On the other hand, the word gold, which is phonetically not dissimilar to clone, has existed for more than a thousand years and still refers to the same chemical element. We must conclude that the multiple meanings of clone are not due to popular usage, but to the desire of scientists, unhampered by any regulatory body, to extend the term to a variety of newly discovered phenomena with only partially overlapping characteristics. In the process, the original meaning of clone has been almost forgotten, even though it should still play an important role in the science of fruit growing. For instance, edible bananas are always seedless, and several hundred clones are thought to exist, of which more that half are triploid. ${ }^{112}$ It is to be hoped that the term will not be abandoned in its appropriate setting because it has been pre-empted for different purposes in the biomedical sciences.

The history of the term clone illustrates the danger of placing concepts with only partially overlapping characteristics under one umbrella designation, particularly in communications between scientists and the general public. In a recent essay about the genome, Horace Freeland Judson commented on the confusion engendered by the use of the term "gene" in place of "allele", and wrote that "Public misinformation is largely and in origin the fault of scientists themselves" ${ }^{113}$ Sloppy nomenclature provides a fertile soil for the media and writers of science fiction to play on people's ancient mistrust of scientists. It is hardly surprising that the word clone-whose meaning has run the gamut from plants that are merely transplanted parts of the same individual, to sheep and humans with very different origins-provided such an opportunity. Evidently, far more vigilance is needed on the part of referees and editors to ensure accurate usage of scientific terms.

\footnotetext{
${ }^{108}$ Jacek Z Kubiak, Martin H Johnson, 'Human infertility, reproductive cloning and nuclear transfer: a confusion of meanings', Bioessays, 2001, 23: 359-64.

${ }^{109}$ Webber, op. cit., note 8 above.

${ }^{110} \mathrm{~T}$ H Savory, The language of science, 2nd ed., London, André Deutsch, 1967, p. 112.
}

\footnotetext{
${ }^{111}$ Ibid., pp. 47-63, 88-111.

$112 \mathrm{~J}$ W Purseglove, Tropical crops: monocotyledons 2, Harlow, Longman, 1972, pp. 351-5.

${ }^{113}$ Horace Freeland Judson, 'Talking about the genome', Nature, 2001, 409: 769.
} 


\section{Ursula Mittwoch}

When terminology shifts, specialists, like so many Humpty Dumpties, will be able to discern the intended meaning correctly, but the general public, just like Alice, will be confused when confronted by ambiguous information. ${ }^{14}$ Popular confusion is likely to perpetuate the long tradition of mistrusting grand claims made by scientists.

${ }^{114}$ Even readers of Nature (2001, 412: 848) may be puzzled by a recent 'News in brief' piece headed 'No charge for Japan's cloned mice', which begins: "The mouse clones that formed the backbone of the international effort to make sense of the mouse genome ... are to be made available to researchers free of charge." When it is further stated that 21,000 clones have been given away, it becomes clear that the information is not about mice but pieces of DNA. 